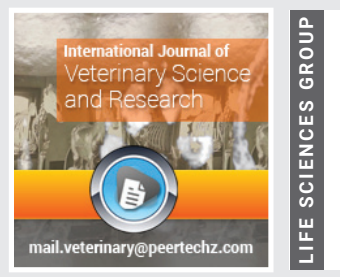

\title{
Traditional cattle breeding practices and rate of inbreeding in the mid rift valley of Oromia, Ethiopia
}

Received: 14 August, 2021

Accepted: 13 September, 2021

Published: 14 September, 2021

*Corresponding author: Aman Gudeto, Adami Tulu Agriculture Research Center, Ethiopia, E-mail: amangude13@gmail.com

Keywords: Cattle breeding practice; Cattle identification; Rate of inbreeding; Animal selection criteria

https://www.peertechzpublications.com

\section{Check for updates}

\author{
Aman Gudeto $^{1 *}$, Tadele Mirkena ${ }^{2}$ and Tesfaye Kebede ${ }^{3}$ \\ ${ }^{1}$ Adami Tulu Agriculture Research Center, Ethiopia \\ ${ }^{2}$ Food and Agriculture Organization of United Nation (FAO), Addis Ababa, Ethiopia \\ ${ }^{3}$ Norwegian University of life science, Norway
}

\begin{abstract}
The study was conducted in Adami Tulu Jidokombolcha, Bora, Dodola, Shala and Negele-Arsi districts with the objective of assessing cattle breeding practices and the rate of inbreeding. Two hundred forty respondents were identified using random sampling techniques. The study's results indicated that farmers traditionally use names and ear cuts to identify their local cattle. Body size was ranked as the primary selection criteria for bulls, while reproductive fitness and milk yield traits were primordial selection criteria for cows. Many of the respondents rear bulls for draught purposes, while few of them rear them for breeding purposes. The study indicated that breeding was mostly panmectic as most of the bulls were owned communally. The findings revealed that the majority of respondents were unaware of the negative effects of inbreeding. Most of the respondents practiced culling of unproductive cattle. Poor reproductive fitness and milk yield were frequently used as primary culling criteria for cows, while poor draft power and old age were ranked as prime culling criteria for male cattle. The information generated on farmers' breeding practices should be used as a baseline for future cattle breeding improvement strategy in the studied and similar areas.
\end{abstract}

\section{Introduction}

Ethiopia has the largest livestock population in East Africa. The livestock sector has been contributing a considerable portion to the economy of the country and still promises to rally around the economic development of the country. The total cattle population is estimated to be above $65,354,090$ million [1]. From the total population, $55.48 \%$ and $44.62 \%$ are female and male cattle, respectively. The majority of cattle (98.95\%) are indigenous, with the remainder being hybrid and exotic breeds. However, the production and productivity of cattle does not match their population size [2].

There is no systematic and organized selection scheme for cattle genetic improvement in Ethiopia [3]. Cattle genetic improvement is focused on crossbreeding by importing live animals or semen, which is less successful in adaptability and productivity. Cross breeding done mainly without consideration of local cattle breeding practices might not be sustainable and cause genetic erosion of the indigenous cattle population.

Traditional livestock rearing systems are inclined to maintain diversity among the livestock types within their herds. Indigenous livestock breeds are products of specific ecological and socio-cultural environments, suitable for surviving under inherent challenges. However, our farmers do not use records for evaluation of cattle performance; rather, they are dependent on conformational traits to select their animals for breeding [4].

Farmers tend to select the best breeding stock based on different phenotypic parameters. They provide their cows/ bulls for breeding purposes for their acquaintances based on different selection criteria. Cattle producers in Ethiopia prefer to select their cattle based on marketable traits such as milk yield, growth rate, and reproductive fitness. Farmers in the East Gojjam Zone select cows based on the body conformation 
and history of their dams [5]. Such information is necessary for decision making in the breed improvement programme [6].

Inbreeding is the mating of closely related individuals, and its consequences increase the chances of deleterious traits' expression and decrease animal production [7]. Knowledge of effective population size is important in predicting the rate of loss of genetic variation. Information on the rate of inbreeding is important in designing a breeding strategy and selection scheme for the improvement of indigenous cattle breeds [8].

Arsi cattle are one of thirty-four identified breeds of cattle in Ethiopia. The Arsi cattle breed is distributed throughout the Arsi, West Arsi and some parts of Shoa [9]. The breed is well adapted to the semi-arid to highland agro-ecology of the area. The Arsi cattle are mainly reared for milk and drought power purposes. In the cattle production system, to undertake intervention for improvement in their productivity and to design a sustainable breeding program, it is essential to identify the knowledge of farmers on the breeding practice of animals and the rate of inbreeding. However, information on the rate of inbreeding of cattle reared in study areas is scant. Therefore, the study was initiated with the objective of assessing farmers' breeding practices and the rate of inbreeding in the mid-rift valley of Oromia.

\section{Materials and methods}

\section{Description of study areas}

The study was conducted in the Adami Tulu JidoKombolcha (ATJK), Bora, Dodola, Shala and Negele-Arsi districts which are located in the mid-rift of Oromia. ATJK, Bora and Negele-Arsi are situated on the main road from Addis Ababa to Shashamane and located at 110,160 , and $226 \mathrm{~km}$ south of Addis Ababa city, respectively. Dodola district is located $324 \mathrm{~km}$ south-east of Addis Ababa on the main Addis Ababa-Shashamane-Bale Robe road. Shala district is located $28 \mathrm{~km}$ south of Addis Ababa on the main Addis Ababa-Shashamane-Wolaita road.

\section{Sample and design of sampling}

A multi-stage sampling technique was employed for the selection of study districts. As a result, ATJK and Bora from the East Shoa Zone were purposefully chosen, while Dodola, Shala, and Negele-Arsi from the West Arsi Zone were chosen based on cattle potential in the Zones. The samples were proportionate to the total number of farmers per district. Accordingly, a total of 240 households were randomly selected and interviewed. Two kebele were selected from each district based on their Arsi cattle potential and famers who own cattle were listed and randomly selected for the interview.

\section{Data gathering}

A semi-structured questionnaire was developed and tested before administration. Some re-arrangements, reframing, and corrections were done after the questionnaire test. The questionnaire included the animal identification system, cattle selection criteria, mating system, inbreeding knowledge, culling method, culling criteria, and castration practices. Enumerators were employed and trained on data collection. Every respondent was informed about the objective of the study while conducting the survey. Focus group and key informant discussions were conducted to strengthen the data from the semi-structured questionnaire survey. The group discussion mainly focused on naming sources and selection criteria of cattle.

\section{Methods of data analysis}

Questionnaire data gathered during the study period was checked for any errors, coded, and entered into an excel spreadsheet. The SPSS statistical software version twenty-four was used to analyses survey data. Indices were done for bulls and cows' selection criteria as following:

Where, $\mathrm{Rn}=$ value given for the least ranked level (if the least rank is $5^{\text {th }}$, then $\left.R n=5, R n-1, R 1=1\right), C n=$ count of the least ranked level (in the above level example, the count of the $5^{\text {th }}=$ $\mathrm{Cn}$, and the count of the $1^{\text {st }}$ rank = C1) [10].

For a randomly mated population, the rate of inbreeding from effective population size was calculated as $\mathrm{Ne}=4 \mathrm{NmNf} /$ $(\mathrm{Nm}+\mathrm{Nf})$

Where Nm denotes the number of breeding males and $\mathrm{Nf}$ denotes the number of breeding females.

$\mathrm{Ne}=$ Effective population size

$\Delta \mathrm{F}=1 / 2 \mathrm{Ne}$ where $\Delta \mathrm{F}$ : inbreeding coefficient (Falconer, 1989)

\section{Results and discussions}

\section{Identification system for cattle}

The findings as presented in Table 1 indicate that cattle are usually provided with names by their owners for common understanding within the family and to call the animals. The focus groups indicated that the names were given to the cattle based on their coat colour, coat colour pattern, horn orientation, tail colour, reproduction, production, pedigree and behaviour of the individual animal. The famer names his/her animals in order to communicate with his family members: which animal

\begin{tabular}{|c|c|c|}
\hline Naming sources & Local names & Description of the name given to the animal \\
\hline \multirow{3}{*}{ Coat colour } & Burree & Cattle are black with white coats. \\
\hline & Gurraa & Cattle have a black coat colour. \\
\hline & Arroo & Cattle have a brown coat colour. \\
\hline \multirow{3}{*}{ Horn shape } & Baajii & Cattle with downward horns \\
\hline & Doobbaa & Upward, curved, long-horned cattle \\
\hline & Fiilaa & upward erected long-horned cattle \\
\hline Tail colour & Muta & $\begin{array}{l}\text { Cattle with white tail particularly at end of its } \\
\text { length }\end{array}$ \\
\hline Behaviour & Finchila & Aggressive cattle \\
\hline \multirow[t]{2}{*}{ Source of cattle } & Handhura & Cattle gifted to child at birth time \\
\hline & Gegai & $\begin{array}{l}\text { Cattle were gifted to a lady during her marriage } \\
\text { time. }\end{array}$ \\
\hline Reproduction & Tadhi & The cow has a short calving interval. \\
\hline \multirow[t]{2}{*}{ Production } & Otticha & The cow has more milk production. \\
\hline & Baakku & The cow has less milk production. \\
\hline Pedigree & Arro-tiko & $\begin{array}{l}\text { Daughter name and prefix is a dam's name called } \\
\text { Arro. }\end{array}$ \\
\hline
\end{tabular}

Local names' origins are the Afan Oromo Language.

Citation: Gudeto A, Mirkena T, Kebede T (2021) Traditional cattle breeding practices and rate of inbreeding in the mid rift valley of Oromia, Ethiopia. Int J Vet Sci Res 7(2): 077-082. DOI: https://dx.doi.org/10.17352/ijvsr.000084 
is sick, which animal is absent from the herd, which animal is going to be culled, which animal is going to be sold, and so on. Moreover, the focus group discussion indicated that modern animal identification systems and records were not practiced in the farming community.

In addition to naming the cattle, ear cutting was practiced in the communities. According to the focus group discussion, a farmer cuts his or her cattle's ears with a blade at different ear positions. Cattle ear cutting positions in one community are different from others. For instance, "Haabbaloossa, Habbarnoossa, Doodda, Abbayi" are small clans of Arsi society. "Haabbaloossa" clan cuts the ears of their herd in a similar fashion, which is different from the remaining clans. These traditional cattle identification systems need to be further studied and well documented (figures 1-5).

\section{The selection criteria of breeding animals}

The findings as presented in Table 2 correspond to selection of bulls and cows based on some predefined traits. The bulls are selected based on their body size, and those with a large body frame are the prime features for selection, followed by physical appearance and the performance of their dam. Other traits which are considered are docility, libido and calf survivability. The study also indicated that the cows are selected based on their reproduction ability and milk yield, which interchanged between the study areas. This is closely followed by the size of the cows, where the smaller ones were preferred against the larger ones. According to the group discussion, cows of large size have lower resistance to surviving in prolonged drought seasons than cows of small body size. Cows were also selected based on their physical appearance in many places. Focus group discussion indicated that male farmers prefer cows with short calving intervals than cows with long calving intervals to increase their herd numbers, while females prefer cows with long calving intervals to get more milk from their cows as a result of the extended lactation period.

According to the findings presented in Table 2, bulls are selected based on their body size, physical appearance, and dam performance, besides their docility. Bull body size is an important trait because it is associated with masculinity and such bulls typically have a high carcass yield [11]. Body size is a primordial trait for selection criteria, which is in close accordance with the observations of Bayou, et al. [12] who stated that large body size animals have better draft power, higher milk yields, better market price and good growth rate. The second most important trait which is considered for selection is the physical appearance (coat colour, external body traits and overall view) of the bulls those with even slight physical deformities are not preferred. Ftiwi and Tamir [13] reported that the physical appearance has more aesthetic reasons than economic considerations. The performance of the dam as a selection criterion indicates that the respondents were aware of the transmission of the dairy related traits from the dam to the bull calves. Dairy related traits are moderately heritable and therefore the information from the female relatives can serve as an indication of the transmission ability of the trait by the male offspring [14]. The study further indicates that

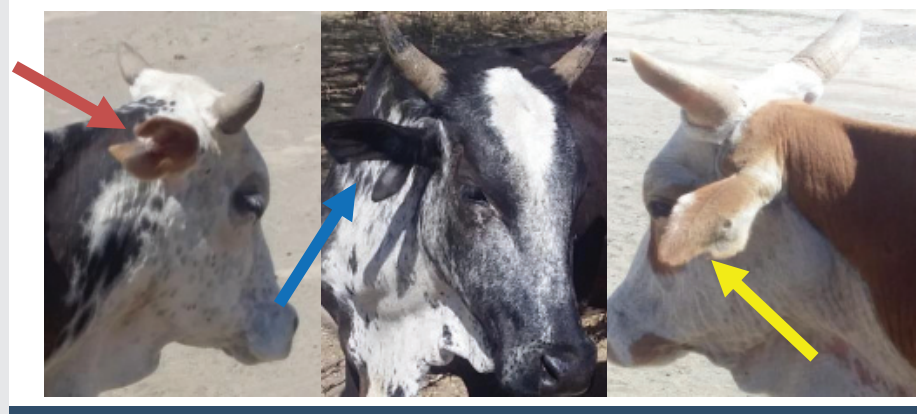

Figures 1-3: Single ear cutting at different size and position.

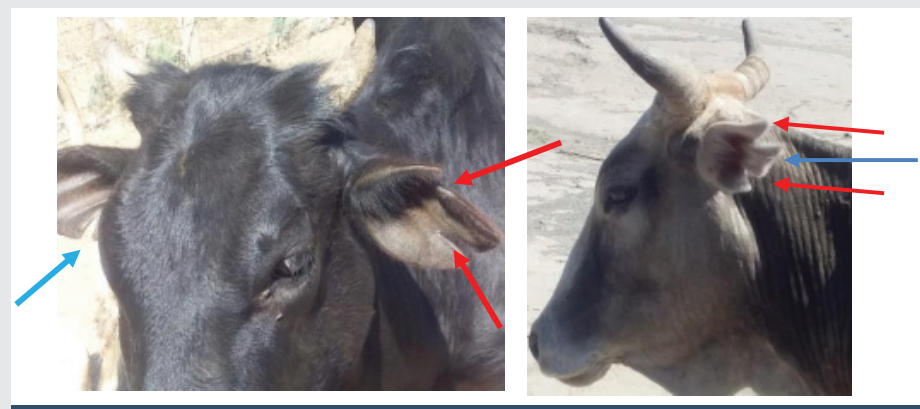

Figures 4-5: Show multiple ear cuts in various positions.

Table 2: Selection criteria for the bulls and cows in the studied areas.

\begin{tabular}{|c|c|c|c|c|c|c|c|c|c|c|c|c|}
\hline \multirow{3}{*}{ Bull } & \multicolumn{12}{|c|}{ District } \\
\hline & \multicolumn{2}{|c|}{ ATJK } & \multicolumn{2}{|c|}{ Bora } & \multicolumn{2}{|c|}{ Dodola } & \multicolumn{2}{|c|}{ Shala } & \multicolumn{2}{|c|}{ Negele-Arsi } & \multicolumn{2}{|c|}{ Overall } \\
\hline & Index & Rank & Index & Rank & Index & Rank & Index & Rank & Index & Rank & Index & Rank \\
\hline Body size & 0.32 & 1 & 0.28 & 1 & 0.3 & 1 & 0.29 & 1 & 0.27 & 1 & 0.28 & 1 \\
\hline PA & 0.26 & 2 & 0.18 & 2 & 0.26 & 2 & 0.25 & 2 & 0.24 & 2 & 0.23 & 2 \\
\hline DP & 0.21 & 3 & 0.17 & 3 & 0.14 & 4 & 0.18 & 3 & 0.21 & 3 & 0.18 & 3 \\
\hline Docility & 0.11 & 4 & 0.15 & 4 & 0.16 & 3 & 0.1 & 5 & 0.08 & 6 & 0.13 & 4 \\
\hline Libido & 0.06 & 5 & 0.13 & 5 & 0.1 & 5 & 0.11 & 4 & 0.12 & 4 & 0.11 & 5 \\
\hline CSRS & 0.04 & 6 & 0.09 & 6 & 0.04 & 6 & 0.07 & 6 & 0.08 & 5 & 0.06 & 6 \\
\hline \multicolumn{13}{|l|}{ Cow } \\
\hline Body size & 0.17 & 3 & 0.16 & 3 & 0.19 & 3 & 0.18 & 4 & 0.17 & 3 & 0.18 & 3 \\
\hline PA & 0.15 & 4 & 0.13 & 5 & 0.14 & 4 & 0.2 & 3 & 0.16 & 4 & 0.14 & 4 \\
\hline Milk yield & 0.23 & 2 & 0.21 & 2 & 0.27 & 1 & 0.22 & 2 & 0.25 & 1 & 0.25 & 2 \\
\hline RF & 0.25 & 1 & 0.23 & 1 & 0.21 & 2 & 0.24 & 1 & 0.23 & 2 & 0.26 & 1 \\
\hline DP & 0.13 & 5 & 0.2 & 4 & 0.11 & 5 & 0.1 & 5 & 0.12 & 5 & 0.1 & 5 \\
\hline Docility & 0.07 & 6 & 0.07 & 6 & 0.08 & 6 & 0.06 & 6 & 0.07 & 6 & 0.05 & 6 \\
\hline
\end{tabular}

PA: Physical Appearance, DP: Dam Performance, CSRS: Calf Survival and its Resemblance to Sire, RF: Reproductive Fitness 
docility was also taken as criteria for selection of the bulls as docile bulls are easy to manage and hence are expected to have a very good temperament [13]. Bulls with good libido during mating are considered good for reproduction [15].

As presented in Table 2, the findings show that the cows are selected based on their reproduction fitness, milk production, body size and their physical appearances, which are in similar agreement with the findings of Tewelde, et al. [11]. The cows are selected based on their primarily based on reproductive fitness and milk yield, which are in close accordance with those of Adarge, et al. [5]. This is because the cows with good milk yield can nurse strong claves and also some extra milk can be made available to the family members. Belay and Minale [15] reported that primary selection criteria for cows are based on milk production levels and reproductive fitness rather than body size. Cows with long bodies usually have higher abdominal space for the growing foetus, and cows with a wide pelvic region have lower incidences of non-specified abortion [16]. Moreover, studies have indicated that cows with longer and larger bodies require higher maintenance but can be correlated with high milk yield [14]. Results refer to the physical appearance of the cows, which include well developed udders, milk veins, a thin and long neck, and rounded barrels. Cows with good physical appearances have a pleasing effect on their owners and also on the social hierarchy of the herd.

\section{Breeding bulls' source and mating system}

The findings refer to the breeding bull sources and mating systems as reported by the respondents (Table 3 ). The result showed that most of the bulls used for breeding in the study areas were owed communally. The study indicates that natural mating is common within livestock herds in the current study areas [17]. The panmaxia prevails under an extensive livestock husbandry system [18]. Other studies also reported that natural mating was common practice and bulls were available from their own herd and from neighbours [4]. In general, Panmaxia leads to lower chances of inbreeding as each bull has equal chances of mating with its opposite sex. However, in the absence of adequate numbers of good bulls in the herd, it often leads to negative selection and increases the chances of inbreeding. Panmaxia allows supply of milk yield all year round, but calving during a feed scarce period leads to low milk yield, slow calf growth, and low calf survival [13].

\section{Bull possession, the purpose of bull rearing and inbree- ding knowledge}

The results pertaining to the bull possession, purpose of bull rearing and inbreeding knowledge of the respondents are illustrated in figure 6 . The figure indicates that few of the respondents kept bulls for breeding purposes only. The finding also indicated that most respondents did not have knowledge of the inbreeding ill effects.

The respondent bull possession as it is prevailing in the study areas indicates that some of the respondents reared bulls while some of them did not rear any. Rearing of bulls is important, especially when artificial insemination services are not regular in the area. However, the use of bulls has to be carefully monitored so as to prevent the spread of any venereal diseases. The study also indicates that most of the bulls reared may have been used for draft purposes as very few respondents raised bulls solely for breeding purposes. Focus group discussion indicated that rearing of bulls is desisted by many farmers because of economic reasons. Andarge, et al. [5] reported that small-holder farmers in the East Gojjam Zone keep bulls for both breeding and drought power. The study indicates that few farmers selected bulls from their herds and reared them only for breeding purposes, which is in accordance with the findings of Ftiwi and Tamir [13] from the Northern part of Ethiopia. The study further indicated that most respondents were not aware of the ill effects of inbreeding. Animal inbreeding increases the chances of deleterious traits' expression and reduces the productivity of cattle.

\section{Effective population size and rate of inbreeding}

The effective population size in the individual herd and mixed herd of cattle was calculated in Table 4. The study results indicate that there is no significant difference among the districts in breeding males, effective population size and inbreeding coefficient. The effective population size in the individual herd is relatively higher in Shala and lower in Bora than in the other districts. The cattle have a chance of mixing during common grazing time. The combined effective

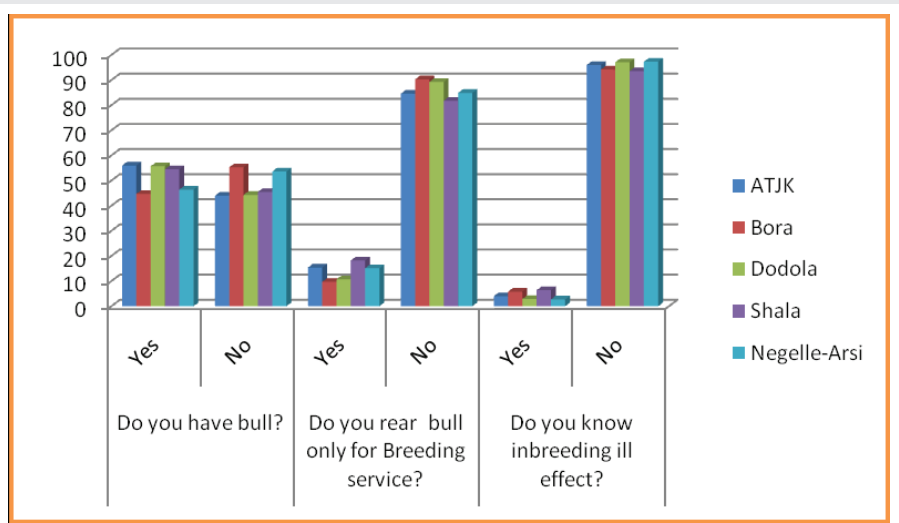

Figure 6: Bull possession, purpose of bull rearing and ill effects of inbreeding

Table 3: Breeding bulls sources, mating system and culling methods frequency (\%).

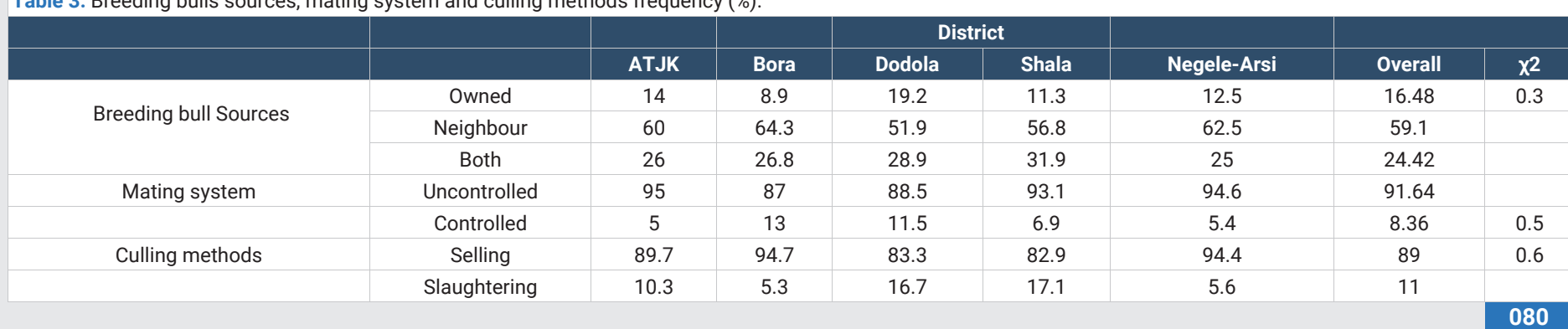

Citation: Gudeto A, Mirkena T, Kebede T (2021) Traditional cattle breeding practices and rate of inbreeding in the mid rift valley of Oromia, Ethiopia. Int J Vet Sci Res 7(2): 077-082. DOI: https://dx.doi.org/10.17352/ijvsr.000084 
Table 4: Effective population size and the rate of inbreeding in study areas.

\begin{tabular}{|c|c|c|c|c|c|c|c|}
\hline & & & & District & & & \\
\hline Herd & & ATJK & Bora & Dodola & Shala & Negele-Arsi & Overall \\
\hline \multirow{5}{*}{$\mathrm{HH}$ herd mean } & $\mathrm{Nm}$ & 1.56 & 1.13 & 1.44 & 1.72 & 1.26 & 1.422 \\
\hline & $\mathrm{Nf}$ & 5.14 & 3.65 & 5.23 & 5.61 & 4.6 & 4.85 \\
\hline & $\mathrm{BM} / \mathrm{F}$ & 0.20 & 0.18 & 0.18 & 0.20 & 0.19 & 0.18 \\
\hline & $\mathrm{Ne}$ & 4.78 & 3.45 & 4.51 & 5.26 & 3.95 & 4.39 \\
\hline & $\Delta \mathrm{F}(\%)$ & 10 & 14 & 11 & 9 & 12 & 11 \\
\hline \multirow{5}{*}{ Combined herd } & $\mathrm{Nm}$ & 78 & 43 & 75 & 76 & 71 & 68.6 \\
\hline & $\mathrm{Nf}$ & 257 & 139 & 272 & 247 & 250 & 233 \\
\hline & $\mathrm{BM} / \mathrm{F}$ & 0.303 & 0.309 & 0.275 & 0.307 & 0.284 & 0.294 \\
\hline & $\mathrm{Ne}$ & 239.3 & 131.4 & 235.16 & 232.5 & 221.18 & 211.98 \\
\hline & $\Delta \mathrm{F}(\%)$ & 0.208 & 0.380 & 0.212 & 0.215 & 0.226 & 0.235 \\
\hline
\end{tabular}

BM/F: Ratio of Breeding Male to Female; HH: House Hold; Ne: Effective population size; $\Delta F$ : Coefficient of inbreeding

population size is lower in the Bora district than in others.

Effective population size is a measure of genetic variability within a population and large values indicate more variability, whereas small values show less variability [8]. The finding indicates that cattle reared in the Bora district are relatively more inbred. The study also indicates that cattle reared in the Shala district are under less danger of inbreeding than others at $\mathrm{HH}$ herd mean level. The low level of inbreeding is an indication that the population is not under threat [8]. The study's findings were consistent with the findings of Ayeneshet, et al. [7], who found that cattle raised in the Gondar Zone have a low inbreeding rate.

\section{Cattle culling and bull castration practices}

The result in figure 7 is indicative that culling is common among the herds owned by the respondents and so was castration. The figure indicates that Dodola district's farmers have lower castration practice than other study areas.

The results, as indicated in figure 7 , show that culling of bulls prevails in the study areas, which is in close accordance with the findings of Tariku [19]. The culling of unproductive animals is a common practice, as it allows the meagre resources in the form of feed and water to be used by the less productive animals. The findings in Table 3 indicated that most respondents cull their cattle mostly in the form of selling them to earn extra cash for their households, and few in the form of slaughtering them for home consumption or religious purposes.

Castration is an important tool to avoid unwanted breeding bulls and minimizing the chances of inbreeding within a herd [20]. It is also an essential farm operation. It is carried out with various aims, viz., to bring about docility of the bulls, improve draft power, and fattening performances. The findings show that most of the respondents castrate to make bulls tame for different farming activities besides preventing unwanted mating, which is similar with the report of Andarge, et al. [5] from East Gojjam Zone. Castrated bulls are preferable for traction and fattening since their energy goes from reproduction to draft power. However, focus group discussion indicated that bull castrations are on a decreasing trend because of the bulls being sold after two to three years of ploughing these days. Cattle castrations are done after being mature, which is in close accordance with the finding of Endashaw, et al. [21] in the southern part of the country. Castration of young calves needs to be carried out at a younger age, as it helps to prevent unwanted mating and is less painful for them.

\section{Cattle culling criteria in the study area}

The findings as presented in Table 5 correspond to culling criteria of male and female cattle based on some predefined traits. Culling is an important farm practice which enables the respondents to select the best cattle from the herd [22]. Most of the time, female cattle are culled from the herd due to poor productive fitness (sterility, repeated abortions), low milk production potential, and old age. The respondents also indicated that the male cattle are often culled due to poor draft power, old age and bad behavior.

The results indicated that farmers have a culling mechanism to maintain the desired quality of their animals. Cattle culling criteria that often prevail in the study areas are in close accordance with the findings of Ayantu, et al. [23] from the Horro district. The respondents reported that lazy or poordrafted power oxen or bulls are a curse for owners since they do not finish ploughing at the required time. The old male cattle are also usually the next to be culled out of the herd because such animals have poor draft ability. Moreover, bulls with bad temperament can cause grievous injuries to both the handlers and other animals within the herd. It may also take a long time and extra labour to tame them. According to the findings, poor reproductive fitness is the primary criterion for culling cows, which is similar to the report by Enanit [24] cows, can lead to a delay in conception; hence, such females are better to be identified and culled.

\section{Conclusion and recommendation}

Farmers have their own cattle identification mechanism to identify their local cattle. They names their cattle based on

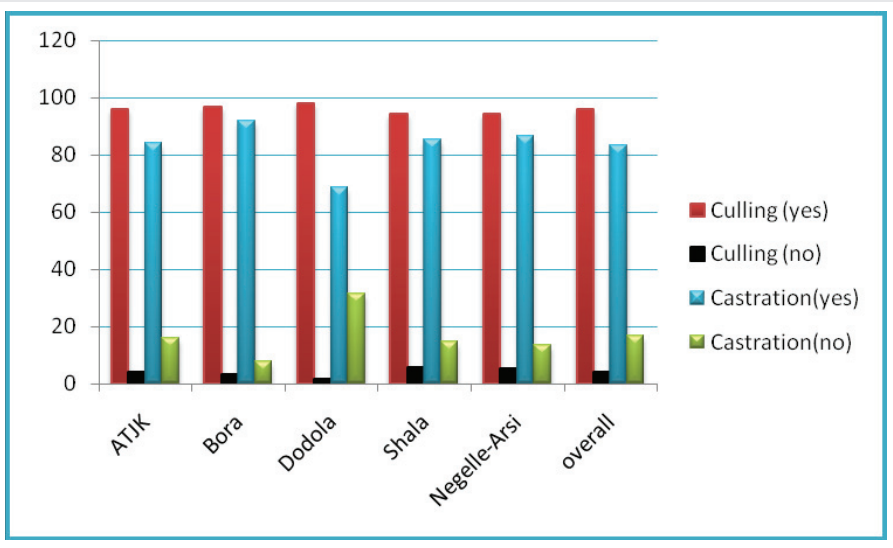

Figure 7: Frequency of the culling and castration.

Table 5: Main cattle culling criteria in the study areas.

\begin{tabular}{|c|c|c|c|}
\hline Female cattle & indexes & Male cattle & Indexes \\
\hline Old age & 0.365 & Old age & 0.331 \\
\hline Poor reproductive fitness & 0.387 & Poor draft power & 0.395 \\
\hline Low milk production & 0.248 & Bad temperament & 0.274 \\
\hline
\end{tabular}

Citation: Gudeto A, Mirkena T, Kebede T (2021) Traditional cattle breeding practices and rate of inbreeding in the mid rift valley of Oromia, Ethiopia. Int J Vet Sci Res 7(2): 077-082. DOI: https://dx.doi.org/10.17352/ijvsr.000084 
some phenotype feature. Cattle keepers practice selection of parent stock for the next generation based on a few selection criteria. Body size is the primary selection criteria for bulls, while reproductive fitness and milk production traits are selection criteria for breeding cows.

Farmers hold bulls mainly for draft purposes, which might have an effect on the breeding efficiency of bulls. Farmer awareness is needed about the ill effects of inbreeding in cattle. However, cattle in the study areas have a low level of inbreeding rate, which indicates that the cattle populations reared in the areas are not under threat for the time being.

Exploiting the local knowledge of managing herds, setting breeding goals, and designing mating systems with cattle keeper participation is of paramount importance in genetic improvement. This, cattle breeding practices can be used as baseline information for future cattle breeding improvement programs in the study areas.

\section{Acknowledgement}

Firstly, I give thanks to the School of Animal and Range Sciences, College of Agriculture, Hawassa University, for providing the research methodology. I am also grateful to the Oromia Agriculture Research Institute for funding the research. I would also like to extend my appreciation to the Adami Tulu Agriculture Research Centre for technical support and for enabling me to have a conducive working environment during and after the study.

\section{References}

1. CSA (Central Statistical Authority) (2019/20) Agricultural sampling survey, report on livestock and livestock characteristics for the year 2019/2020, Addis Ababa, Ethiopia.

2. Abera A (2019) Review on breeding objectives and practices of dairy cattle production in Ethiopia. Journal of Cell and Animal Biology 13: 1-7. Link: https://bit.ly/3liTLHe

3. Hailu A, Abate M (2016) Community Breeding Practice and the Challenges in Dairy Cattle Management in North Gondar, Ethiopia. International Journal of Environmental \&Agriculture Research (IJOEAR) 2: 2454-1850. Link: https://bit.ly/3EblfpE

4. Misganaw G, Wuletaw Z, Ayalew W (2014) Breeding practices in indigenous dairy cattle breeds in Northern Amhara, Ethiopia. Livestock research for rural development 26. Link: https://bit.ly/3tBXEe1

5. Zewdu A, Alemayehu K, Wondifraw Z (2018) Breeding Practices and Farmers Trait Preferences on Indigenous Dairy Cattle Production in East Gojjam Zone. Asian Journal of Agriculture and Food Sciences 06: 2321-1571. Link: https://bit.ly/3kcya49

6. Legesse D (2016) Dairy cattle breeding in Ethiopia. Journal of Biology, Agriculture and Healthcare 6: 2224-3208

7. Ayeneshet B, Wondifraw Z, Abera M (2017) Production Objectives, Breeding Practices and Rate of Inbreeding in Dairy Cows at Alefa and Quara Districts of North Gondar Zone, Amhara National Regional State, Ethiopia. Int J Anim Sci 1: 1011. Link: https://bit.ly/3zb8ysq
8. Moses DO (2016) Assessing Effective Population Size and Rate of Inbreeding in Bunaji Cattle under Pastoral Production System. PAT 12: 155-160. Link: https://bit.ly/3A958b5

9. DAGRIS (Domestic Animal Genetic Resources Information System) (2018) International Livestock Research Institute, Addis Ababa, Ethiopia.

10. Tilahun M, Angassa A, Abebe A, Mengistu A (2016) Perception and attitude of pastoralists on the use and conservation of rangeland resources in Afar Region, Ethiopia. Ecological Processes 5: 18. Link: https://bit.ly/3k1NgsV

11. Gebru T, Yigrem S, Banerjee S (2017) Some morphometrical, production and reproduction in Begait cattle reared at Tigray Region of Ethiopia. Wayamba Journal of Animals Science 9: 1571-1585. Link: https://bit.ly/3hs2Jks

12. Bayou E, Haile A, Gizaw S, Mekasha Y (2014) Characterizing husbandry practices and breeding objectives of Sheko cattle owners for designing conservation and improvement strategies in Ethiopia. Livestock Research for Rural Development 26. Link: https://bit.ly/3z1hv7C

13. Ftiwi M, Tamir B (2015) On-Farm Phenotypic Characterization of Indigenous Begait Cattle in Western Tigray, Northern Ethiopia. J Anim Pro Adv 5: 718-732. Link: https://bit.ly/3hrVrx2

14. Getu A, Misganaw G (2015) The role of conformational traits on dairy cattle production and Utility longevity. Open Accass Library Journal 2. Link: https://bit.ly/399l2WN

15. Zeleke B, Getachew M (2017) Traditional Cattle Husbandry Practice in Gamo Gofa Zone, Southern Western Ethiopia. International Journal of Nove Research in Life Sciences 4: 1-7. Link: https://bit.ly/39230dZ

16. Mokonnen M, Moges N (2016) A review on Dostocia and cows. European Journal Biological Sciences 8: 91-100. Link: https://bit.ly/3htvWLF

17. Bekuma A, Fita L, Galmessa U (2020) Breeding Practices, Reproductive and Productive Performance of Dairy Cows: The Case of West Wollega Zone Gimbi District, Ethiopia. J Fertil In vitro IVF World Reprod Med Genet Stem Cell Biol 8: 3

18. Beriso K, Tamir B, Feyera T (2015) Characterization of Smallholder Cattle Milk Production System in Aleta Chukko District, Southern Ethiopia. J Adv Dairy Res 3: 132. Link: https://bit.ly/2YHXhTS

19. Woldeyohannes T (2020) Assessment of Husbandry Practices, Production and Reproductive Performance of Indigenous Cattle in Hadiya Zone, Southern Ethiopia. International Research Journal of Science and Technology 1: 177 198. Link: https://bit.ly/3lhdU0h

20. Dioli M (2018) Nomad aesthetic: Cattle modifications among the northern Turkana of North West Kenya. Research, policy and practice 8: 1-10. Link: https://bit.ly/3EcTP40

21. Terefe E, Dessie T, Haile A, Mulatu W, Mwai O (2012) Husbandry and breeding practices of cattle in Mursi and Bodi pastoral communities in South West Ethiopia. African Journal of Agriculture Research 7: 5986-5994. Link: https://bit.ly/3k6v8yg

22. Mezgebe G, Gizaw S, Urge M, Chavhan A (2017) Begait cattle production systems and production performances in northern Ethiopia. Int J Life Sciences 5. Link: https://bit.ly/38ZToeY

23. Mekonnen A, Haile A, Dessie T, Mekasha Y (2012) On farm characterization of Horro cattle breed production systems in W-estern Oromia, Ethiopia. Livestock Research for Rural Development 24. Link: https://bit.ly/2Xe9EpW

24. Sisay E (2017) Study on Productive and Reproductive Performance of Dairy Cows and Management Practices of Smallholder Dairy Farmers in Lay Armachiho district, North Gondar Zone, M.Sc. Thesis, Submitted to the faculty of veterinary medicine, University of Gondar.

Copyright: @ 2021 Gudeto A, et al. This is an open-access article distributed under the terms of the Creative Commons Attribution License, which permits unrestricted use distribution, and reproduction in any medium, provided the original author and source are credited.

Citation: Gudeto A, Mirkena T, Kebede T (2021) Traditional cattle breeding practices and rate of inbreeding in the mid rift valley of Oromia, Ethiopia. Int J Vet Sci Res 7(2): 077-082. DOI: https://dx.doi.org/10.17352/ijvsr.000084 